\title{
SEGURANÇA NO CUIDADO EM CIRURGIAS: ONDE ESTAMOS?
}

DOI: 10.5327/Z1414-4425201500020001

A temática sobre a segurança em cirurgia surgiu como meta do segundo desafio global lançado pela Aliança Mundial para a Segurança do Paciente, da Organização Mundial da Saúde (OMS), entre 2007 e 2008, tendo como marco a campanha "Cirurgia Segura Salva Vidas". Tal campanha teve como objetivo estimular os gestores de instituições hospitalares, bem como os profissionais de saúde, a mobilizarem esforços no sentido de elencar um padrão de práticas que: promovesse a segurança em cirurgia, fosse aplicável em qualquer parte do mundo e em diferentes cenários cirúrgicos, permitisse a mensuração de indicadores visando a promoção de vigilância epidemiológica. Desses esforços surgiram protocolos assistenciais e listas de verificação cirúrgica aplicáveis no intraoperatório. A lista de verificação mais conhecida é o Time Out, e sua utilização é um dos requisitos de várias instituições acreditadoras, dentre elas a The Joint Commission, que criou o seu protocolo universal. Os resultados satisfatórios da aplicação do Time Out são inegáveis e a cada dia mais profissionais de saúde envolvidos com o cenário cirúrgico estão mudando de hábito e "parando" para responder ao checklist e confirmar se aquele paciente a ser submetido a uma cirurgia é o paciente certo, se o procedimento a ser realizado é o correto, se o sítio cirúrgico a ser abordado é o correto, dentre outras importantes informações. Porém, outras atividades relacionadas ao procedimento anestésico cirúrgico, mas que não ocorrem no momento de início da cirurgia, são de suma importância para a promoção da segurança do paciente e devem ser valoradas. Podemos citar o gerenciamento da limpeza ambiental, a gestão de custos, o adequado processamento dos artigos de assistência à saúde, o dimensionamento adequado de pessoal no bloco cirúrgico, a capacitação permanente da equipe de enfermagem diante das novas tecnologias, a assistência de enfermagem na recuperação anestésica e a comunicação entre as equipes. Embora o desafio global "Cirurgia Segura Salva Vidas" tenha sido lançado há oito anos, percebe-se que ainda há um longo caminho a percorrer na promoção da segurança em cirurgia e, mais do que o preenchimento do checklist, os profissionais envolvidos com o ato anestésico-cirúrgico devem resgatar as origens de sua formação humanística e ética. Essa é uma tarefa de todos os envolvidos no processo: profissionais, educadores, pesquisadores, pacientes e gestores. Sugiro um questionamento simples, para verificar o quanto estamos colaborando para esse processo: "caso eu necessite de um procedimento anestésico-cirúrgico, o quanto me sentiria seguro em ser submetido a uma cirurgia em meu próprio local de trabalho?”.

Profa. Dra. Eliane da Silva Grazziano Professora adjunta do Departamento de Enfermagem da UFSCar, São Paulo (SP), Brasil. 